\title{
CHILD \& LABOUR SCENARIO IN ODISHA
}

\author{
Samir Kumar Nanda*
}

\begin{abstract}
Based upon research in the state of Odisha in India, this article describes the labour scenario in the state of Odisha during the last 82 years. Odisha became separate state on 1st April 1936. Eighty-two years since the momentous day, much has changed in the Labour relation, Juveniles, Child Labour problem \& Migrant Workers of Odisha. This article also explains the magnitude of child labour and steps taken by the Government to eliminate child labour, formation of Labour Union, status of migrant workers and bonded labour in the state of Odisha. Here an effort has been made to analyse the status of child labours as well as other labours in Odisha. Identification of the area of concentration of child labour \& evaluations of dimensions of the problem has been made.
\end{abstract}

Key Words: Odisha. Child Labour.NCLP. Sarva Sikshya Abhiyan \& Dadan Labour

\section{RESUMO}

Com base em pesquisas no estado de Odisha, na Índia, este artigo descreve o cenário de trabalho nos últimos 82 anos. Odisha tornou-se estado separado em $1^{\circ}$ de abril de 1936. Passados oitenta e dois anos desde o dia da independênica, muita coisa mudou na relação trabalhista seja juvenil, seja no que tange o problema do trabalho infantil e dos trabalhadores migrantes de Odisha. Este artigo também explica a magnitude do trabalho infantil e as medidas tomadas pelo governo para eliminá-lo, a formação do sindicato, a situação dos trabalhadores migrantes e o trabalho escravo. Neste estudo, foi feito um esforço para analisar o status do trabalho infantil, bem como de outros tipos trabalhos em Odisha. Foi feita a identificação da área de concentração do trabalho infantil e avaliações das dimensões do problema.

Palavras-chave: Odisha. Trabalho infantil. Sarva Sikshya Abhiyan e Dadan Labor

\section{INTRODUCTION}

Despite its vast natural and human resources and substantial progress achieved during the last 50 years plan of development. Odisha continues to be one of the less developed States in India. The history of Odisha dates back to antiquity, its most famous old names being Kalinga, Utkal and Odra, when its boundary extends far

$\begin{array}{lr}\text { *M.A (Labour } & \text { Laws), } \\ \text { MBA, LLB, } & \text { PhD } \\ \text { (Sociolog), } & \text { Member } \\ \text { Juvenile Justice } & \text { Board, } \\ \text { Government of } & \text { Odisha, } \\ \text { India. } & \text { Email- } \\ \text { drsamir.2015@gmail.com }\end{array}$


beyond the present one. By the time of the Mahabharata Kalinga, Utkal and Odra had entered into Aryan polity as powerful kingdoms. An unbroken history of the unusual people of this land, has continued since several centuries before Christ. It has left its imprint in the shape of numerous monuments and every passing day, excavation brings to light more and more of such sites from almost all parts of the state. They reveal the existence of a flourishing civilization, striking by any standard. Few other cultures in all the senses of the term are as rich and as varied. In the sphere of religion and philosophy, tribal and Aryan religions, Buddhism and Jainism, Islam and Christianity-all have existed in history and they continue side by side even now as a testimony to the religious tolerance of the people of this land. In art and architecture, centuries of history survive in the shape of temples and even today they survive in replicas which provide livelihood to the descendents of the ancient practitioners of these arts.

The names signified different territorial extent ruled by different dynasties of rulers at different periods. Each of these comprised large areas of current Odisha but also included areas forming parts of the neighbouring states. With the freedom movement of India, a revolution was started for unifying all the outlaying Odia speaking areas into a separate state. For this purpose, Sri Madhusudan Das set up an organization called "Utkal Sammilani" in 1903. Sir Basudev Sudhal Deb,KCIE,CIE, king of erstwhile Bamanda state was invited by Sri Madhusudan Das to preside over the first meeting of the Utkal Sammilani. But, it was not possible due to sudden demise of Sir Basudev Sudhal Deb.At last Odisha became separate state on $1^{\text {st }}$ April 1936. Struggle of many Odia leaders \& intellectuals during three decades led to the formation of Odisha State. The Government of Orissa celebrated the assent of the President of India to the erroneous Orissa (Alteration of Name) Bill, 2010 that tampers with classicism of Oriya language by enforcing change of the State's English spelling from Orissa to Odisha with effect from November 01, 2011 Eighty-two years since the momentous day, much has changed in the Labour relation, Juveniles, Child Labour problem \& Migrant Workers of Odisha. Let's discuss the journey of Odisha state as well as the difficulties it faced since 1936.

\section{CHILD LABOUR}


According to Justice P.N.Bhagwati, former Chief Justice of India “ The child is a soul with a being, a nature and capacities of its own, who must be helped to find them, to grow into their maturity, into a fullness of physical and vital energy and the utmost breadth ,depth and height of its emotional, intellectual and spiritual being; otherwise there cannot be a healthy growth of the nation".

The World is now believed to have come into extremes i.e. either children to work or they go to school. All extremes child labour debates focus attention to the problems of elimination of child labour. It is in consonance with the objectives of the International Labour Conference of 1979, India adopts mix prohibit measures as well as measures for humanising child labour. The legal protection relates to total ban of employment of children below the age of 14 years and ban of adolescents labour below 18 years in hazardous employments. Sri Kailash Satyarthi has stated that, despite the number of legislations, practice of child labour in both unorganized and organized sectors is not only going on but is also increasing day-by-day. Dr.Helen.R.Sekar described about how labour officials worried about diverse obstacles in enforcing child labour laws. Dr.R.N.Mishra has indicated in his study that, in Odisha the coastal districts with long coast line have affected regularly by natural calamities while the districts of Western Odisha are drought prone area. As $60 \%$ of the population of Odisha is under BPL Category therefore due to poverty child labour is engaged in various types of hazardous and non-hazardous sectors.

Almost each of us from our childhood goes through the various phases of education. This over the years brings about the best in each one of us, both in term of creativity \&learning. Empowerment plays the most predominate role in shaping us. We acknowledge that elimination of child labour is a task that needs patient effort and even certain insensitivity to taunts and threats from interested quarters. We are certain that in course of time, it will be quite possible to ensure that the child is protected from economic exploitations, hazardous work or interference with the child's education or anything harmful to the child's health or physical, mental, spiritual, moral or social development. We are committed to such a possibility and call upon all righteous people to join us in this effort.

The economic rationale of child labour is the contribution it makes to household income and lack of consciousness in the case of poor households. In such a situation, it 
becomes important to know the nature of work in which a child labourer is engaged and how hazardous it is. Since child labour means educational deprivation, it also becomes equally important to facilitate access to non-formal schooling for child labourers. Government of Odisha and the Central Government have adopted various programme for the eradication of child labour in Odisha. These programme have given good results. The Government officials now a day take very sensitive steps against such activities. In order to eliminate child labour the Govt. of Odisha has passed Orissa Child Labour (Prohibition and Regulation) Rules, 1994 vide Notification No. S.R.O. 219/94, dated 24th February, 1994*. In exercise of the powers conferred by sections 13 and 18 of the said Act, the State Government formed State Action Plan for Elimination of Child Labour.

A sample survey on child labour was conducted by the Labour Directorate of Government of Odisha in 1990-91 \& the report was published under the title "Socio Economic Condition of Child Labour in Orissa". The survey was undertaken on the occasion of SAARC**(South Asian Association for Regional Cooperation) Year of Girl Child in 1990. Subsequently another survey on child labour in Odisha was conducted in the year 1995-96 which depicts more comprehensive approach to the problem with the inclusion of agricultural sector. There were 831664 child labours identified in the state which was $2.63 \%$ of the population. Findings of the Department of School and Mass Education through the survey conducted by Sarva Shikshya Abhiyan in 2007-08 indicate the number of out of school children at 2.70 lakh.

As per the guidelines issued by the Ministry of Labour \& Employment, Government of India the survey and identification of child labour should be conducted twice in each plan period with the financial assistance of Govt. of India. As per the survey conducted in the year 1997 with the directives of the Hon'ble Supreme Court of India 2,15,222 number of child labours were identified in the State of Odisha. However, following numbers of child labours were found in the State of Odisha as per the different census report of India.

$\begin{array}{ccccl}1971 & 1981 & 1991 & 2001 & 2011 \\ 4,92,477 & 7,02,293 & 4,52,394 & 3,77,594 & 92,087\end{array}$

From the above figures we can observe that the percentage of number of child 
labour has increased $43 \%$ in the year 1981 in comparison to 1971 Census whereas the percentagehas decreased up to $36 \%$ in the 1991 census in comparison to 1981 and $17 \%$ decreased in 2001 in comparison to 1991 and decreased 75\% in 2011 in comparison to 2001 census. If we compare the census report of 1971 and 2001 than we find the percentage has decreased to $23 \%$ over the years. As per the said guidelines of Government of India the child labour survey were conducted in Deogarh district with the funds sanctioned by Govt. of India in the year 2005,2011 and 2016 by the NCLP \& District Administration with the help of State Labour Institute, Odisha Bhubaneswar. As per the survey report 10014,7163 and 1875 numbers of child labours were identified in the district respectively.

The State Level Coordination Committee on elimination of child labour headed by Additional Chief Secretary has been constituted vide Labour \& Employment Department Resolution. The Committee held its $1^{\text {st }}$ meeting on $7^{\text {th }}$ November 1998 to expeditiously implement the directives of Hon'ble Supreme Court of India***. Subsequently, District Level Task Force Committee on Child Labour headed by the Collector and District Level Monitoring Committee of Labour has been also constituted in each district of the State in the year 2012 \&2015 respectively. District Level Task Force for Beedi Workers is also functioning for the betterment of the Beedi Workers in each district.

\section{*Orissa Child Labour (Prohibition and Regulation) Rules, 1994 Notification No. S.R.O. 219/94, dated 24th February, 1994.}

Whereas, the draft of the Orissa Child Labour (Prohibition and Regulation) Rules, 1993, was published as required by subsection (18)(1) of the Child Labour (Prohibition and Regulation) Act (No. 61 of 1986), in the Extraordinary issue of the Orissa Gazette, dated 23rd August, 1993, under the notification of the Government of Orissa in the Labour and Employment Department dated 26th July, 1993, inviting objections and suggestions from all persons likely to be affected thereby till the expiry of a period of two months from the date of publication of the said notification in the Orissa Gazette; And whereas no objection or suggestion has been received from any person in respect of the said draft by the State Government during the aforesaid period; Now, therefore, in exercise of the powers conferred by sections 13 and 18 of the said 
Act, the State Government do hereby make the following rules, namely:

Section 1. These rules may be called the Orissa Child Labour (Prohibition and Regulation) Rules, 1949. They shall come into force on the date of their publication in the Orissa Gazette.

Section 2. Definitions.

Section 3. Working hours. -The number of hours of work which shall constitute a normal working day as required under subsection (7)(1) of the Act shall be four and a half hours with one-hour rest after first three hours of work.

Section 4. Maintenance of register under section 11. -Every occupier of an establishment shall maintain a register in respect of children employed or permitted to work. The register shall be maintained on yearly basis but shall be retained by the employer for a period of three years, after the date of the last entry made therein.

Section 5. Certificate of age.

a) All young persons in employment or seeking employment in any of the occupations set forth in Part "A" of the Schedule or in any workshop wherein any of the processes set forth in Part "B" of the Schedule is carried on, shall produce a certificate of age from the appropriate medical authority, whenever required to do so by an Inspector.

b) The appropriate "medical authority" for the purpose of subsection (1) shall be a Government Medical Officer not below the rank of an Assistant Civil Surgeon of a District or a regular doctor of equivalent rank employed in the Employees' State Insurance Dispensaries or Hospitals. (3) The certificate of age as referred to in subsection (1) shall be issued in Form "B" and no fee shall be charged for the same.

Section 6. Prohibition of employment of child labour in dangerous operations.

The following areas shall be deemed to be of dangerous character where the employment of child labour shall be prohibited, namely:

a) dangerous machines, including power process other than hydraulic process, milling machines used in metal trades, guillotine machines, circular saws plates 
and printing machines;

b) work machinery in motion;

c) self-acting machines;

d) carrying of excessive weights beyond $16 \mathrm{kgs}$ in case of male child, and $13 \mathrm{kgs}$ in case of female child;

e) explosives;

f) inflammable dust, gas, etc;

g) exposure to chemical and toxic substances; and

h) cotton ginning.

Section 7. Protection of child labour.

a) The establishment employing child labour shall provide the following protection in the following works for child labour, namely:

$\checkmark$ Protection of eyes. Effective screening and suitable goggles shall be provided for protection of eyes in the following processes, namely:

- welding or cutting of metals by means of an electric OZY - acetylene or similar processes,

- ail works on furnaces where there is risk of exposures to excessive light,

- processes relating to cutting or forging of metals, and

- any other processes where there is risk to eyes.

- Fencing of machinery;

- Protection from fire and explosive risks;

- Protection from leakage of inflammable liquids; and

- Safety valves for closed vessels in which gas is passed and in which the pressure is liable to risk to a dangerous degree.

b) Adequate precautions shall be taken to prevent the emission of effluents which may be dangerous or poisonous.

c) Breathing apparatus shall be provided in operations, where dangerous gas or fume is liable to escape.

Section 8. Health measures. 
a) every establishment shall be kept clean and free from effluvia arising from any drain, privy or other nuisance.

b) effective and suitable provisions shall be made in every establishment for securing and maintaining healthy atmosphere in work room by providing the following facilities, namely:

$\checkmark$ adequate ventilation for the circulation of fresh air; and

$\checkmark$ such temperatures as will require for the workers for reasonable conditions of comfort and prevention of injury to health.

c) in every establishment effective arrangement shall be made to provide and maintain at suitable points conveniently situated for all child labourers employed therein a sufficient supply of wholesome drinking water.

d) in every establishment sufficient latrines and urinal accommodations shall be provided.

Section 9. Safety education.

Every establishment employing child labour shall impart sufficient safety education to the child labour before their engagement

\section{THE CHILD LABOUR (PROHIBITION AND REGULATION) AMENDMENT ACT, 2016 NO. 35 OF 2016 [29th July, 2016.]}

An Act further to amend the Child Labour (Prohibition and Regulation) Act, 1986.

BE it enacted by Parliament in the Sixty-seventh Year of the Republic of India as follows:

1. (1) This Act may be called the Child Labour (Prohibition and Regulation) Amendment Act, 2016.

(2) It shall come into force on such date as the Central Government may, by notification in the Official Gazette, 
In the Child Labour (Prohibition and Regulation) Act, 1986 (hereinafter referred to as the principal Act), for the long title, the following shall be substituted, namely: — "An Act to prohibit the engagement of children in all occupations and to prohibit the engagement of adolescents in hazardous occupations and processes and the matters connected therewith or incidental thereto.".

Short title and commencement. Amendment of long title. 61 of 1986.

The following Act of Parliament received the assent of the President on the 29th July, 2016, and is hereby published for general information

3. In section 1 of the principal Act, in sub-section (1), for the words, brackets and figures "the Child Labour (Prohibition and Regulation) Act, 1986", the words, brackets and figures "the Child and Adolescent Labour (Prohibition and Regulation) Act, 1986" shall be substituted.

4. In section 2 of the principal Act,- (a) clause (i) shall be renumbered as clause (ia) thereof and before clause (ia) as so renumbered, the following clause shall be inserted, namely:- '(i) "adolescent" means a person who has completed his fourteenth year of age but has not completed his eighteenth year;'; (b) for clause (ii), the following clause shall be substituted, namely:- '(ii) "child" means a person who has not completed his fourteenth year of age or such age as may be specified in the Right of Children to Free and Compulsory Education Act, 2009, whichever is more;'.

5. For section 3 of the principal Act, the following section shall be substituted, namely: - "3. (1) No child shall be employed or permitted to work in any occupation or process. (2) Nothing in sub-section (1) shall apply where the child,- - (a) helps his family or family enterprise, which is other than any hazardous occupations or processes set forth in the Schedule, after his school hours or during vacations; (b) works as an artist in an audio-visual entertainment industry, including advertisement, films, television serials or any such other entertainment or sports activities except the circus, subject to such conditions and safety measures, as may be prescribed: Provided that no such work under this clause shall effect the school education of the child. Explanation.-For the purposes of this section, the expression, (a) "family" in relation to a child, means his mother, father, brother, sister and father's sister and brother and mother's sister and brother; (b) 'family 
enterprise" means any work, profession, manufacture or business which is performed by the members of the family with the engagement of other persons; (c) "artist" means a child who performs or practices any work as a hobby or profession directly involving him as an actor, singer, sports person or in such other activity as may be prescribed relating to the entertainment or sports activities falling under clause (b) of sub-section (2).'.

6. After section 3 of the principal Act, the following section shall be inserted, namely: - "3A. No adolescent shall be employed or permitted to work in any of the hazardous occupations or processes set forth in the Schedule: Provided that the Central Government may, by notification, specify the nature of the non-hazardous work to which an adolescent may be permitted to work under this Act.'”

Amendment of short title. Amendment of section 2. Substitution of new section for section 3. Prohibition of employment of children in any occupation and process. Insertion of new section 3A. Prohibition of employment of adolescents in certain hazardous occupations and processes.

7. In section 4 of the principal Act, for the words "add any occupation or process to the Schedule", the words "add to, or, omit from, the Schedule any hazardous occupation or process" shall be substituted.

8. In section 5 of the principal Act, - (i) in the marginal heading, for the words " Child Labour Technical Advisory Committee", the words "Technical Advisory Committee" shall be substituted; (ii) in sub-section (1), for the words "Child Labour Technical Advisory Committee", the words "Technical Advisory Committee" shall be substituted.

9. In the heading of Part III of the principal Act, for "CHILDREN" substitute "ADOLESCENTS.".

10. In section 6 of the principal Act, for the word and figure "section 3", the word, figure and letter "section $3 \mathrm{~A}$ " shall be substituted.

11. In section 7 of the principal Act, for the word "child", wherever it occurs, the word "adolescent" shall be substituted.

12. In section 8 of the principal Act, for the word "child", the word "adolescent" shall be substituted. 
13. In section 9 of the principal Act, for the word "child", at both the places, where it occurs, the word "'adolescent"' shall be substituted.

14. In section 10 of the principal Act, for the word "child", at both the places, where it occurs, the word "'adolescent"' shall be substituted.

15. In section 11 of the principal Act, - (a) for the word "children", the word "'adolescent"' shall be substituted. (b) for the word "child", wherever it occurs the word "adolescent"' shall be substituted.

16. In section 12 of the principal Act, - (a) in the marginal heading, for the words and figures "sections 3 and 14" the words, figures and letter "sections $3 \mathrm{~A}$ and 14" shall be substituted; (b) for the words and figures "sections 3 and 14", the words, figures and letter "sections $3 \mathrm{~A}$ and 14" shall be substituted.

17. In section 13 of the principal Act, for the word "children', wherever it occurs, the word "adolescent"' shall be substituted.

18. In section 14 of the principal Act,- (a) for sub-section (1), the following subsections shall be substituted, namely:- "(1) Whoever employs any child or permits any child to work in contravention of the provisions of section 3 shall be punishable with imprisonment for a term which shall not be less than six months but which may extend to two years, or with fine which shall not be less than twenty thousand rupees but which may extend to fifty thousand rupees, or with both: Provided that the parents or guardians of such children shall not be punished unless they permit such child for commercial purposes in contravention of the provisions of section 3 . (IA) Whoever employs any adolescent or permits any adolescent to work in contravention of the provisions of section $3 \mathrm{~A}$ shall be punishable with imprisonment for a term which shall not be less than six months but which may extend to two years or with fine which shall not be less than twenty thousand rupees but which may extend to fifty thousand rupees, or with both:

Provided that the parents or guardians of such adolescent shall not be punished unless they permit such adolescent to work in contravention of the provisions of section 3A. (1B) Notwithstanding anything contained in sub-sections (1) and (1A) the parents or guardians of any child or adolescent referred to in section 3 or section 3A, shall not be liable for punishment, in case of the first offence.". (b) for subsection (2), the following sub-sections shall be substituted, namely: — “(2) 
Whoever, having been convicted of an offence under section 3 or section $3 \mathrm{~A}$ commits a like offence afterwards, he shall be punishable with imprisonment for a term which shall not be less than one year but which may extend to three years. (2A) Notwithstanding anything contained in sub-section (2), the parents or guardian having been convicted of an offence under section 3 or section $3 \mathrm{~A}$, commits a like offence afterwards, he shall be punishable with a fine which may extend to ten thousand rupees.". (c) clauses (a), (b) and (c) of sub-section (3) shall be omitted.

19. After section 14 of the principal Act, the following sections shall be inserted, namely: - "14A. Notwithstanding anything contained in the Code of Criminal Procedure, 1973, any offence committed by an employer and punishable under section 3 or section 3A shall be cognizable. 14B. (1) The appropriate Government shall constitute a Fund in every district or for two or more districts to be called the Child and Adolescent Labour Rehabilitation Fund to which the amount of the fine realized from the employer of the child and adolescent, within the jurisdiction of such district or districts, shall be credited. (2) The appropriate Government shall credit an amount of fifteen thousand rupees to the Fund for each child or adolescent for whom the fine amount has been credited under sub-section (1). (3) The amount credited to the Fund under sub-sections (1) and (2) shall be deposited in such banks or invested in such manner, as the appropriate Government may decide. (4) The amount deposited or invested, as the case may be under sub-section (3), and the interest accrued on it, shall be paid to the child or adolescent in whose favour such amount is credited, in such manner as may be prescribed. Explanation: - For the purposes of appropriate Government, the Central Government shall include the Administrator or the Lieutenant Governor of a Union territory under article 239A of the Constitution. 14C. The child or adolescent, who is employed in contravention of the provisions of this Act and rescued, shall be rehabilitated in accordance with the laws for the time being in force. 14D. (1) Notwithstanding anything contained in the Code of Criminal Procedure, 1973, the District Magistrate may, on the application of the accused person, compound any offence committed for the first time by him, under sub-section (3) of section 14 or any offence committed by an accused person being parent or a guardian, in such manner and on payment of such amount to the appropriate Government, as may be prescribed. Insertion of new sections 14A, 14B, 
14C and 14D. Child and Adolescent Labour Rehabilitation Fund. Rehabilitation of rescued child or adolescent. Compounding of offences. 2 of 1974. 2 of 1974. Offences to be Congnizable. SEC. 15 (2) If the accused fails to pay such amount for composition of the offence, then, the proceedings shall be continued against such person in accordance with the provisions of this Act. (3) Where any offence is compounded before the institution of any prosecution, no prosecution shall be instituted in relation to such offence, against the offender in relation to whom the offence is so compounded. (4) Where the composition of any offence is made after the institution of any prosecution, such composition shall be brought in writing, to the notice of the Court in which the prosecution is pending and on the approval of the composition of the offence being given, the person against whom the offence is so compounded, shall be discharged.".

20. After section 17, the following sections shall be inserted, namely: "17A. The appropriate Government may confer such powers and impose such duties on a District Magistrate as may be necessary, to ensure that the provisions of this Act are properly carried out and the District Magistrate may specify the officer, subordinate to him, who shall exercise all or any of the powers, and perform all or any of the duties, so conferred or imposed and the local limits within which such powers or duties shall be carried out by the officer as may be prescribed. 17B. The appropriate Government shall make or cause to be made periodic inspection of the places at which the employment of children is prohibited and hazardous occupations or processes are carried out at such intervals as it thinks fit, and monitor the issues, relating to the provisions of this Act.".

21. In section 18 of the principal Act, in sub-section (2),- (i) clause (a) shall be relettered as clause (b) thereof and before clause (b), as so relettered, the following clause shall be inserted, namely:- (a) the conditions and the safety measures under clause (b) of sub-section (2) and other activities under clause (b) to Explanation of sub-section (2) of section 3; (ii) in clause (b), as so relettered, for the words "Child Labour Technical Advisory Committee", the words "Technical Advisory Committee" shall be substituted. (iii) clauses (b), (c) and (d) shall be relettered as clauses (c), (d) and (e) thereof and in clause (c) as so relettered, for the word "child", the word "adolescent" shall be substituted; (iv) after clause (e), as so 
relettered, the following clauses shall be inserted, namely:- "(f) the manner of payment of amount to the child or adolescent under sub-section (4) of section 14B; (g) the manner of composition of the offence and payment of amount to the appropriate Government under sub-section (1) of section section 14D; (h) the powers to be exercised and the duties to be performed by the officer specified and the local limits within which such powers or duties shall be carried out under section 17A.". Insertion of new sections 17A and 17B. District Magistrate to implement the provisions. Inspection and monitoring. Amendment of section 18.

22. In the principal Act, for the Schedule, the following Schedule shall be substituted, namely: 'THE SCHEDULE (See section 3A) (1) Mines. (2) Inflammable substances or explosives. (3) Hazardous process. Explanation. For the purposes of this Schedule, "hazardous process" has the meaning assigned to it in clause (cb) of the Factories Act, 1948.'.

\section{** The South Asian Association for Regional Cooperation (SAARC)}

was established with the signing of the SAARC Charter in Dhaka on 8 December 1985. SAARC comprises of eight Member States: Afghanistan, Bangladesh, Bhutan, India, Maldives, Nepal, Pakistan and Sri Lanka. The Secretariat of the Association was set up in Kathmandu on 17 January 1987. The fourth summit was held in Islamabad, Pakistan on 29-31 December 1988 and was attended by the presidents of Bangladesh, the Maldives and Sri Lanka, the prime ministers of India and Pakistan, and the kings of Bhutan and Nepal. The summit discussed the coup attempt on 3 November 1988, declared 1989 to be the "SAARC Year Against Drug Abuse", declared 1990 to be the "SAARC Year of the Girl Child", The Heads of State or Government decided that in order to maintain focus on the problems of the Girl Child the years 1991-2000 AD would be observed as the "SAARC Decade of the Girl Child". They were deeply moved by the SAARC Girl Child's appeal for love and care for them and their right to childhood. They reiterated their resolve that the welfare of the child in general and the girl child in particular, would figure at the top of their list of priorities.

\section{*** Directives of hon'ble supreme court of India}

On 10th December 1996 in Writ Petition (Civil) No.465/1986 on MC Mehta 
verses state of Tamil Nadu the Supreme Court of India, gave certain directions on the issue of elimination of child labour. The main features of judgment are as under:

a) survey for identification of working children;

b) withdrawal of children working in hazardous industry and ensuring their education in appropriate institutions;

c) contribution @ Rs. 20,000/- per child to be paid by the offending employers of children to a welfare fund to be established for this purpose;

d) employment to one adult member of the family of the child so withdrawn from work and it that is not possible a contribution of Rs. 5,000/- to the welfare fund to be made by the State Government;

e) financial assistance to the families of the children so withdrawn to be paid -out of the interest earnings on the corpus of Rs. 20,000/ Rs. 25,000/- deposited in the welfare fund as long as the child is actually sent to the schools;

f) regulating hours of work for children working in non-hazardous occupations so that their working hours do not exceed six hours per day and education for at least two hours is ensured. The entire expenditure on education is to be borne by the concerned employer.

g) the implementation of the direction of the Hon'ble Supreme Court is being monitored by the Ministry of Labour and compliance of the directions have been reported in the form of Affidavits on 05.12.97, 21.12.1999, 04.12.2000, 04.07.2001 and 04-12-2003 to the Hon'ble Court on the basis of the information received from the State/UT Governments.

\section{NATIONAL CHILD LABOUR PROJECT (NCLP)}

National Child Labour Project functioning in 271 districts in 21 states in our country. This is the major scheme for rehabilitation of child labour in the world. The NCLP was first initiated in 1988, as a part of a larger plan of action arising out of the National Policy on Child Labour. Since then it has been supported by several major initiatives at the central, state and district levels aimed at elimination of child labour. A high-powered National Authority for the Elimination of Child Labour (NAECL) was set 
up on 26th June, 1994 comprising Secretaries to the Government of India representing various ministries such as the Ministries of Finance, Women and Child Development, Education, Labour, Welfare, Information \& Broadcasting, Rural Development, Health $\&$ Family Welfare and Textiles. The main functions of the NAECL are a) To lay down policies and programmes for monitoring and coordinating the implementation of child labour projects; and b) To achieve convergence with various concerned Ministries of the Government of India. The main thrust of the NCLP has been to reduce the incidence of child labour in the high-concentration pockets. Providing education through special schools, and subsequently mainstreaming them in regular schools are the major activities under the NCLP at the ground level. The working children are identified through surveys conducted by independent agencies and inspections conducted by the Labour Department of the state governments. On the basis of their reports, children are withdrawn from the labour force. These children are then enrolled in the special schools which provide formal/non-formal education, vocational training, supplementary nutrition, monthly stipend, regular health check-up, etc., and are subsequently mainstreamed in formal education or self-employment within a period of six months to three years of their enrolment in the special schools. However, NCLP's task does not end at mainstreaming of the enrolled children. In order to check and minimize relapse, NCLP also does the follow-up of the mainstreamed children for the next few years, either in further education, or employment. The NCLP runs through various stages of operation viz., (a) establishment of a District Project Office (DPO) in each of the child labour-endemic districts; (b) conducting survey and identification of child labour, particularly in hazardous occupations; (c) opening up of special schools and supporting them; (d) enrolment of working children in the special schools and ensuring their formal/ informal education up to a maximum period of three years; (e) providing midday meals and regular health check-ups to the enrolled children; and finally (f) mainstreaming those children and keeping track of them for a few years after mainstreaming. In order to successfully carry out the above mentioned activities, NCLP's DPOs are expected to (a) establish convergence of services and schemes with other departments; and (b) implement and monitor different labour laws relevant for abolition of child labour. All these stages are components of one integrated approach aimed at not only reducing the intensity of child labour but also effectively contributing 
to the overall development of children belonging to vulnerable sections of the society in the concerned districts, and subsequently at the all-India level.

National Child Labour Project (NCLP) is a Government of India sponsored scheme meant for such children (6-18) who were living an adult like life in childhood. 890 numbers of Child Labour Special Schools were opened in Odisha under the scheme where working children were enrolled, provided with education, nutritive food, monthly stipend of Rs150/-( at present Rs.400/-), health care facilities and marketable vocational skill and finally after three years mainstreamed into the regular schools. These special schools act like a bridge for such children which make them students from labours, give them education from exploitation and admit them in a school instead of engaging at a workplace.

In Odisha the first NCLP was inaugurated in Sambalpur district in the year 1994 however, in other districts NCLP started after 1995. Primarily, in the year 1994 only one NCLP was there and in 1995 NCLP schools were started in 17 districts and in the year 2002 another 06 NCLP districts have been functioning. Under the National Child Labour Project, a total of 675 special learning centres had been opened till December 2002 in which 37,614 child labourers were admitted. Out of this, 35,054 had been mainstreamed to formal schools. Thus, only about 17.5 per cent of child labourers in the state were admitted to special learning centres.

After implementation of NCLP scheme in Western Odisha many changes took place among the identified child labour. During the period from 1994 to 2010 around 162305 child labours have been identified in Western Odisha out of which 83042 students have been enrolled through NCLP Schools which is $51 \%$ of the total child labour. 55\% of child labour students enrolled have been mainstreamed into higher education after passing from NCLP Schools during the period which is $28 \%$ of the total Child labour identified. About 53\% of the students enrolled in NCLP Schools have undergone Vocational Training for self employment after being educated which is $27 \%$ of the total child labour identified in the Western Odisha after implementation of NCLP Scheme. So NCLP Scheme had played a major role for the rehabilitation, identification and mainstreaming of the child labour in Western Odisha. The Project Directors \& the Field Officers (at present Programme Manager) of the National Child Labour Projects of 24 NCLP districts play an important role for the success of the project. It is matter of 
regret that Government of India engage many highly qualified people in different position in National Child Labour Projects functioning throughout the country (for the rehabilitation of child labour) as volunteers with a very negligible honorarium which is less than a labour. In spite of several requests neither the Government of India nor the State Government have considered those staff for regularisation of their services. Ministry of Labour \& Employment,Government of India and the State Labour \& Employment Department exfoliating those highly qualified and experienced staff engaged for the betterment of child \& adolescent labour. The staff engaged in the National Child Labour Projects in the country have no job security and get wages less than that of a peon of the country. One day the whole country will see that the children of those staff will become child labour. In the year 1996-97 Govt. of Odisha declared Project Directors and Field Officers of the NCLP as Inspector under the Child Labour (Prohibition \& Regulation) Act, 1986, the Minimum Wages Act,1948, the Equal Remuneration Act ,1976 and the Beedi \& Cigar Workers (Conditions of Employment) Act,1966 for the smooth implementation of the Labour Laws in the state. National Child Labour Project of Odisha has conducted State Level Sports Meet of the students of 24 NCLP districts for seven times.

Social changes do not happen very easily. People who deal with production in industry often apply erroneously the same yardstick to movements for social and educational transformation too. Nothing could be so usualistic as that. Viewed against the general trend, it is our feeling that consequent on the formation of National Child Labour Project and the various steps taken to reduce child labour and rehabilitate them by the District Administration****, the problem has got considerably reduced which is reflected from the 2001 census figures \& the 2011 census. \{i.e from 377594 of 2001, to 92087 in 2011 \}. This is a great achievement in this state despite of several constraints.

Unfortunately, Letter No: 3201(24), dtd;04.03.2014 of the Labour Commissioner, Odisha, Bhubaneswar addressed to the Collector-cum-Chairman, NCLP instructs all the children studying in NCLP Schools to be mainstreamed at the nearby formal schools run by School and Mass Education Department immediately and such centres shall be closed since no students are left in the NCLP Schools. Accordingly, all the 890 NCLP Special Schools in 24 NCLP districts (in Odisha State only) were closed in the month of May,2014 and the child labours again come to the street. Thousands of 
staff of the concerned NCLP districts who had dedicated their whole life for the rehabilitation and elimination of child labour in the state become beggars as they have no age limit to serve anywhere. It is a matter of regret that the NCLP is still functioning in rest of the states of the Country.

\section{****District administration}

All the 30 districts of Odisha have been placed under three different revenue divisions to streamline their governance. The divisions are Central, North and South with their headquartersat Cuttack (Central Division), Sambalpur (Northern Division), Berhampur (Southern Division) respectively. Each division consists of 10 districts, and has as its administrative head a Revenue Divisional Commissioner (RDC), a senior rank officer of Indian Administrative Service. The position of the $R D C$ in the administrative hierarchy is that between that of the district administration and the state secretariat. The list of districts, organized by divisions:

Collector \& District Magistrate is an Indian Administrative Service (IAS) Officer in charge of revenue collection and administration of a district and Superintendent of Police (SP), an officer of Indian Police Service (IPS) is responsible for maintaining law and order and related issues of a district in Odisha.

The aims and objectives of the District Office $s$ are to assist the District Collector in District Administration. It works as the bridge between the people and administration and thereby popularizing and proliferating the various Government schemes and programmes. Accordingly, there are different sections functioning within this organization for decentralization and successful implementation of multifaceted activities.

\section{ROLE OF JUVENILE COURT TO PROTECT GIRL CHILD ABUSES}

The scheme of prevention and control of the juvenile and social morale judgement is being implemented in the state of Odisha as per the Juvenile Justice Act, 1986 is came into force w.e.f $2^{\text {nd }}$ October 1987. Observation Homes were established in Berhampur, Rourkela, Choudwar. Delinquent and neglected juveniles were admitted, maintain and corrected in those Observation Homes. 


\section{ODISHA STATE CHILD PROTECTION SOCIETY (OSCPS)}

'Child Protection' is about protecting children from or against any perceived or real danger or risk to their life, their personhood and childhood,reducing their vulnerability to any kind of harm and protecting them in harmful situations. ensuring that no child falls out of the social security and safety net and, those who do, receive necessary care, protection and support so as to bring them back into the safety net. While protection is a right of every child, some children are more vulnerable than others and need special attention. The Government recognizes these children as 'children in difficult circumstances', characterized by their specific social, economic and geopolitical situations. In addition to providing a safe environment for these children, it is imperative to ensure that all other children also remain protected. This is because Child protection is integrally linked to every other right of the child.

In exercise of the powers conferred by Section 62A of the Juvenile Justice (Care \& Protection of Children) Amendment Act 2006, State Government vide its notification No. 20825/WCD Dated 03.12.12, to constitute State Child Protection Unit, designated State Child Protection Society formed under ICPS to act as State Child Protection Unit.

Odisha State Child Protection Society (OSCPS) is the technical, fundamental and functional unit of Women \& Child Development Department, Government of Odisha, for implementation of Integrated Child Protection Scheme (ICPS). OSCPS has been registered in the year 2009 under Society Registration Act.

Women and Child development Department has signed a MoU with Ministry of Women and Child Development, GoI to implement Integrated Child Protection Scheme (ICPS) in the state of Odisha through Government and Civil Society Partnership. The aim of ICPS is focused on institutionalizing child protection mechanism and services, effective functioning of existing stake holders and regular capacity building and monitoring of child protection programme \& activities. For creating a safety net for children and to ensure an efficient Juvenile Justice system in the state of Odisha, OSCPS through Integrated Child Protection Scheme lay special emphasis upon the children at most difficult situations such as Child in Need of Care and Protection, Juvenile in Conflict Law, Juvenile in Contact with Law and Other 
Vulnerable Children. Care and Protection of Vulnerable Children are being catered through various protection measures under this scheme. Separate units were set up comprising dedicated and skilled professionals for effective implementation of the scheme.

As per Rule-64 of the Juvenile Justice (Care \& Protection of Children) Orissa Amendment Rules 2009, the specific functions of the State Child Protection Unit includes; implementation of the Juvenile Justice (Care \& Protection of Children) Act and supervision and monitoring of agencies and institutions under the Act, set up, support and monitor the District Child Protection Unit, represent State Child Protection Unit as a member in the selection committee for appointment of boards and committees;

\section{LABOUR UNION}

Labour unions or trade unions are organizations formed by workers from related fields that work for the common interest of its members. They help workers in issues like fairness of pay, good working environment, hours of work and benefits. They represent a cluster of workers and provide a link between the management and workers.

The purpose of these unions is to look into the grievances of wagers and present a collective voice in front of the management. Hence, it acts as the medium of communication between the workers and management.

Regulation of relations, settlement of grievances, raising new demands on behalf of workers, collective bargaining and negotiations are the other key principle functions that these trade unions perform.

The Indian Trade Union Act, 1926, is the principle act which controls and regulates the mechanism of trade unions. In India, political lines and ideologies influence trade union movements. This is the reason why today political parties are forming and running trade unions.

National \& State politics highly affected the labour revolution in Odisha soon after it became a separate province. On $1^{\text {st }}$ March 1938 the first labour union of Odisha namely "Press Workers Union" was founded in Cuttack by Pyari Shankar Rai including the workers of Mission Press, Saraswat Press, Observar Press, Satyabadi Press, 
Nababharat Press, Kohinoor Press \& Manmohan Press. This labour union was registered with the Trade Union Act,1926 as $1^{\text {st }}$ labour union of Odisha bearing registration no 1 . On $1^{\text {st }}$ June 1938 Sri Rai had formed the $2^{\text {nd }}$ labour union with the workers of Cuttack Electricity Company. Till 1940 there were two registered labour unions in Odisha. During 1944 to 1946 around 29 numbers of labour unions were registered in Odisha out of which 19 labour unions were in Cuttack district, 4 numbers were in Sambalpur district ,2 numbers were in Puri district and rest 4 labour unions were functioning in Ganjam district. Twenty years old Sri Sadananda Mohanty was the youngest Labour Union leader in Odisha.Sri Banka Bihari Das had formed the $1^{\text {st }}$ union of domestic servants in Odisha which was registered with the recommendation of the Ramanujam Committee in 1991 by making necessary amendment in the Act. On $16^{\text {th }}$ July 1946 Member, Servants of People Society Sri Shayma Sundar Mishra founded AITUC in Odisha involving 30 labour unions. The union of Primary Teachers in Odisha was first established by the Primary Teachers of Cuttack district in the month of November, 1945. On $1^{\text {st }}$ April 1953 the Labour Directorate was established separately in Odisha for the betterment of the labour force in the state. In different years Government of Odisha has fixed the minimum wages for the unskilled labour in the state as follows:

Prior to 1965 Re.0.62

1965 Re. 1.00

1872 Rs. 2.00

1980 Rs.5.00

1982 Rs.6.00

1985 Rs.7.50

1986 Rs. 10.00

1999 Rs.40.00

2009 Rs. 90.00

2012 Rs. 150.00

2015 Rs. 200.00

2018 Rs. 280.00

\section{DADAN LABOUR (Migrant Workers);}

Migration both within and outside the state is a topic of great relevance in the context of poverty and unemployment. Migration aims to acquire some sort of employment to enhance the family income. This is because of rapid increase in 
population \& poverty prevalent in the rural areas and increase in the cost of leaving as well as aspiration to earn more money. More people migrate in the age group of 35-60.

The Dadan Labour system is a form of labour contract under which people are recruited by middlemen on payment of advance to work in different parts of India. Such a system has all the ingredients of bonded labour system, as is prevalent in Western Odisha,Puri and Ganjam districts . The Orissa Dadan Labour (Control \& Regulation) Act, 1975 enacted by Govt. of Odisha and as per the act all recruiting agents had to register themselves before proceeding to recruit persons. Until the end of February 1976 the act remained merely on the book, without any evidence of its enforcement. With enactment of Interstate Migrant Workmen (Regulation of Employment and Conditions of Service) Act, 1979 it has since been repealed. Children of those migrant workers who are required to stay at home, nourished and take-up studies, left to go in search of better leaving, good food, good clothing and better earnings so that other members of family will live happily. The revelation of the study is seasonal, but the data are inadequate to locate how many children from each district migrate to each state in search of livelihood.

\section{BONDED LABOUR SYSTEM}

There still exists in different parts of our country a system under which the debtor or his descendents have to work along with one or more than one member of the family for the creditor for a specified or an unspecified period without any market wage or without minimum wage notified by the Government in order to discharge a debt. This system originated from the uneven social structure characterized by feudal and semi feudal conditions. It is an outcome of certain categories of indebtedness, like customary obligations, forced labour, beggar or indebtedness which have been prevailing for a long time involving certain economically exploited, helpless and weaker sections of society. They agree to render service to the creditor in lieu of a debt. At times, several generations work under bondage for the repayment of a paltry sum, which had been taken by some remote ancestor, often at usurious rates of interest. This is an unequal exchange system which in its totality represents one of the worst violations of basic human rights and a disgrace to the dignity of labour. 


\section{SECTORS OF THE ECONOMY WHERE BONDED LABOUR SYSTEM IS PREVALENT}

Though the bonded labour system is deeply embedded in feudal and semi-feudal social structure, it is also prevalent in advanced agriculture with landlord serf relationship and in the non-agricultural sectors.

a) high incidence of bonded labour system in the agriculture sector is found in the States of Andhra Pradesh, Bihar, Haryana,Karnataka, Maharashtra, Orissa, Punjab, Tamilnadu and Madhya Pradesh.

b) in the non-agriculture sector, it is prevalent in brick kilns, stone quarries, beedi manufacturing, carpet-weaving, match and fire works industry, pottery, construction projects and bonded child labour in the sericulture processing industry.

c) migrant bonded labour involving States such as Bihar, Jharkhand,Chattisgarh, Tamilnadu, Madhya Pradesh, Orissa, Rajasthan present a heightened form of deprivation and exploitation often amounting to bonded labour system;

d) domestic workers, jogins and devdasis are subjected to exploitation in the form of bonded labour system.

\section{SCHEMES FOR BONDED LABOUR}

In order to assist the State Governments in the task of rehabilitation of identified and released bonded labourers, a Centrally Sponsored Plan Scheme for Rehabilitation of Bonded Labour was in operation since May, 1978. Originally the Scheme provided for rehabilitation assistance up to a ceiling limit of Rs.4000/- per bonded labour to be equally shared by Central Government and State Governments on 50:50 bases. This amount was raised to Rs.6250/- w.e.f 01.02.1986; and to Rs10,000/- w.e.f. 01.04.1995. Out of this, Rs1000/- was to be given as subsistence allowance to meet travel expenses etc. to the state of origin, in case the released bonded labour was to be repatriated to his or her native place/ State or for their subsistence until they are rehabilitated. With effect 
from 01.04.1999, only Rehabilitation assistance was enhanced to Rs. 20,000/-. The scheme was last revised in May 2000 wherein survey component, awareness generation activities and evaluation studies were included as additional items in the existing scheme.

The revised Scheme is a Central Sector Scheme and came into effect from 17th May, 2016.

The Salient features are as follows.:

a) every bonded labour including child bonded labour in the country is covered under the Scheme.

b) the State Governments shall not be required to pay any matching contribution for the purpose of cash rehabilitation assistance. The fund is released by the Ministry of Labour and Employment under the Scheme to the District National Child Labour Project Society and the District Project Society in turn releases the fund to the implementing agencies including the district administration.

c) the amount of assistance for survey of bonded labourers is Rs. 4.50 lakh per district.

d) the Rehabilitation package shall be Rs.1,00,000 per adult male beneficiary. Beneficiary shall have the option to either deposit it in an annuity scheme or receive cash grant. The District Administration will assess the cash requirement of the beneficiary and exercise its best judgment in the matter and put the money under annuity scheme with the consent of the said adult male.

e) for special category beneficiaries such as children including orphans or those rescued from organized and forced begging rings or other forms of forced child labour and women, the amount of rehabilitation assistance shall be 2 lakhs out of which at least Rs 1,25,000/- shall be deposited in an annuity scheme in the name of each beneficiary and the balance amount shall be transferred to the beneficiary account.

f) in cases of bonded or forced labour involving extreme cases of deprivation or marginalization such as trans-genders, or women or children rescued from ostensible sexual exploitation such as brothels, massage parlours, placement agencies etc., or trafficking, or in cases of differently able persons, or in 
situations where the District Magistrate deems fit, the rehabilitation assistance shall be Rs 3 lakhs, out of which at least Rs 2 lakhs shall be deposited in an annuity scheme in the name of each beneficiary and Rs 1 lakh shall be transferred to the beneficiary account .

g) allotment of house-site and agricultural land

h) land development

i) provision of low cost dwelling units

j) animal husbandry, dairy, poultry, piggery etc.

k) wage employment, enforcement of minimum wages etc.

1) collection and processing of minor forest products.

m) supply of essential commodities under targeted public distribution system.

n) education for children.

o) the release of rehabilitation assistance has been linked with conviction of the accused. In cases where the trial has not been concluded, but the District Administration has arrived at a prima facie finding and proof of bondage, then the proposal for cash assistance shall not be stopped for want of details of conviction. However, final disbursement of cash assistance and non-cash assistance shall be made upon proof of bondage and other legal consequences as per judicial process.

p) in cases where, on the conclusion of the summary trial, the District Magistrate (DM) / Sub-Divisional Magistrate (SDM) concludes that the alleged bonded labourer is, in fact, not in a condition of bondage, but requires socio-economic assistance, the DM/SDM, may provide state assistance under any other scheme administered by them.

q) in cases where, the DM/SDM find that immediate assistance is necessary for care and protection of the rescued persons during the pendency of the summary trial, such assistance including food, lodging, medical assistance, legal aid, provisions for victim's or witness' protection, etc., shall be provided under any other law or scheme forthwith, notwithstanding the entitlements prescribed under this scheme.

r) state Governments/Union Territories shall be required to concentrate their efforts on the following activities: 
s) the District Administration in a convergence approach shall undertake measures for providing safe and secure environment for the capacity building of child bonded labourers in coordination with all relevant Government departments. Accordingly, facilities for, ensuring their proper education, psycho social counseling short stay home till education up to class 12th, skill development shall be an integral component of the rehabilitation package.

t) for addressing the special needs of female freed bonded labourers, State Government shall also provide financial and other assistance for marriage, apart from other capacity building measures mentioned earlier.

u) for addressing the needs of the disabled persons, special care should be made available by the State as per national policy for disabled people apart from other capacity building measures.

v) for adult bonded labour who do not come under any of the above categories, employable skill development training shall be a compulsory element of rehabilitation

w) a Bonded Labour Rehabilitation Fund shall be created at the District level by each State with a permanent corpus of at least Rs.10 lakhs at the disposal of the District Magistrate which should be renewable. This fund will be utilized for extending immediate help to the released bonded labourers. The entire penalties recovered from the perpetuators of the bonded labour upon conviction, may be deposited in this special fund.

$\mathrm{x}$ ) immediate assistance of at least Rs 5,000/- shall be provided by the District Administration to the rescued person out of the District Bonded Labour Rehabilitation Fund at the disposal of the District Magistrate. Where the DM is satisfied that a particular rescued person requires more than Rs.5,000, he or she may disburse such higher amount as deemed fit, but limited to the maximum entitlement prescribed under this scheme. Any such advance amount shall be deducted from the Central cash assistance amount.

\section{CONCLUSIONS}

The traditional concept of factors of production namely land,labour,capital and 
organisation is no more accepted phenomenon. Apart from land, the manpower, machine and management are the actual partners of of production in modern economic system. Inclusion of various labour laws, schemes by the Government have enriched the labour scenario of Odisha since its inception. National Child Labour Project plays a vital role for the identification, rehabilitation and mainstreaming of the child labour during last three decades.

\section{REFERENCE}

MISRA, R. N. Problems of child labour in India. New Delhi: Commonwealth Publications, 2004.

NANDA, S. K. Labour scenario in Odisha. Odisha Review, v.73, n. 10, p. 20-25 2017.

NANDA, S. K. Give my Childhood. Bhubaneswar: Publishing House, 2016.

SATYARTHI, K. Child labour issues e rehabilitations. New Delhi: Bhavna Books \& Prints, 2003.

SEKAR, H. R. The MChild Labour (P\&R) Act, 1986 \& itsImplementation, Noida: VVGNLI, 2015.

INDIA. Ministry of Labour e Employment. Census data on clhid labour. India: MLE, 2015. Available in: www.labdirodisha.gov.in-child labour . Access: 29 Jul. 2018.

ODISHA. Labour Directorate. Odisha: Labour Directorate. Available in: www.labdirodisha.gov.in-sli. Access: 29 Jul. 2018. 